\title{
Research of Vitamin D Levels Between the Tuberculosis Infected and Non - Infected Subjects in 16-25 Years of Age
}

\author{
Srishty Mittal, Lakhwinder Kaur
}

\begin{abstract}
Aim - To compare vitamin D levels between $\mathrm{Tb}$ infected and non-infected subjects in 16-25 years of age.

Methods - Tb patients (16-25 years) from low income group were identified from the DOT centres in Pitampura, subjects were interviewed through questionnaire method, analysis of vitamin $D$ content of identified patients and non infected subjects were done and finally assessment of relationship between vitamin $D$ and non infected subjects.

Results- The population included 30 patients infected with $\mathrm{Tb}$ and 30 subjects who are non-infected, which have been tested for vitamin $D$. When results were compared with healthy control group it was found that vitamin $D$ was relatively low i.e. $p$ $<0.001$.There is a high prevalence of VDD in this population.

Conclusion- vitamin $D$ deficiency is positively and significantly co related with $T b$. In the present study, general population itself established to be extremely deficient in Vitamin D. Hence; this is very difficult to delineate relation within VITAMIN $D$ and TB. In future, a multicentre study with a large size of sample needs to be carried out to elicit a relation within vitamin $D$ status and $T B$.
\end{abstract}

Keywords-Directly observed treatment, short course (DOT), Tuberculosis (TB), Vitamin D Deficiency (VDD).

\section{INTRODUCTION}

The possibility of infection caused by TB is associated with deficiency of vitamin $\mathrm{D}(\underline{1}, \underline{2})$. The most prominent and common process by which vitamin $\mathrm{D}$ can eliminate or stagnant the growth of TB infection is by the chelating of vitamin $\mathrm{D}$ in the bioactive formation that is $(1,25-$ dihydroxycholecalciferol) to the receptor of vitamin D (VDR), that controls the genes expression crucial for function of immune system and also take part in production of cytokine $(\underline{3,4,5})$. VDR lies within cells of immune $\underline{(6,7)}$ and pleural and cells of upper lining (pulmonary) $(8,9)$ and control the tying of specific receptors (toll like) (TLRs) in the course of an antimicrobial response $(10,11)$. By this process, calcitriol persuade antimicrobial peptides that are endogenous $(12,13)$ including cathelicidin LL-37 and beta defensin $(6,13)$ also prevent enzymes (matrix metalloproteinase), which damages pulmonary extracellular matrix (14).

Fat soluble vitamin that is D modified the levels of different hormones such as sex hormones $(15,16)$ women had lower vitamin D levels in serum than did men in the present study. Fat content in man on an average is lesser that is $10-15 \%$ as comparison to women having similar value of Body Mass Index (17). Hence, after cutaneous synthesis deposition of fat-soluble vitamin would be lesser in the fat tissue as well as greater would be in the plasma (blood stream) in men (18). VITAMIN D is also removed slower through fat than from blood (19), and to sustain more firm serum levels allover the year the amount of vitamin D might not be in appropriate levels into fat tissue. In addition, women can store more vitamin $\mathrm{D}$ as they are having higher amount of subcutaneous fat $(4,18)$. It has recently been supposed that the binding protein of Vitamin D (DBP) in gender differences in vitamin D status (19) has played a key role. The relation within (percentage body fat) and DBP were positive in women and negative in men (20).

\section{SUBJECTS AND METHODS}

The subjects age group (16-25 years) infected with Tuberculosis were identified and selected through questionnaire method. The questionnaire includes the demographic information such as name, age, gender, food habit etc., anthropometric information such as weight, height, BM. Other questions like information about $\mathrm{Tb}$ and vitamin $\mathrm{D}$ or if they have ever got the $\mathrm{Tb}$ and vitamin $\mathrm{D}$ tested etc.

The present study was conducted in Tuberculosis DOT Centre naming Choudhary Desraj Chest Clinic and Delhi Government Dispensary in Rohini and Pitampura.

The number of subjects selected was of total 60 including both males and females where 30 subjects were infected with $\mathrm{Tb}$ and 30 were non-infected (control group).

Inclusive criteria including people infected with $\mathrm{Tb}$, males and females, age group of 16-25 years of age, which are low-income groups.

Exclusive criteria including subjects below16 years and above 25 years of age.

Vitamin D 25(OH) serum levels were tested in both infected and non infected of the same age group.

Finally, assessment of relationship between vitamin D and control group was done. 
STATISTICAL ANALYSIS

\begin{tabular}{|l|l|l|l|l|l|l|}
\hline & & & & & & \\
& Group & $\mathrm{N}$ & Mean & $\begin{array}{l}\text { Std. } \\
\text { Deviation }\end{array}$ & t-value & p-value \\
\hline \multirow{2}{*}{ WEIGHT } & Group 1 & 30 & 47.60 & 7.70 & 2.889 & 0.005 \\
\cline { 2 - 8 } & Group 2 & 30 & 52.86 & 6.19 & & \\
\hline BMI & Group 1 & 30 & 19.16 & 2.56 & 0.51 & 0.612 \\
\cline { 2 - 8 } & Group 2 & 30 & 19.46 & 1.74 & & \\
\hline VITAMIN D & Group 1 & 30 & 9.94 & 3.18 & 13.258 & $<0.001$ \\
\cline { 2 - 8 } & Group 2 & 30 & 29.07 & 7.21 & & \\
\hline
\end{tabular}

Table1.1 Comparison of Anthropometric Parameters and Vitamin D status among groups

Figure1.3Comparison of mean values in two groups on the basis of Vitamin D

The above1.1 shows Anthropometric Parameters and Vitamin D status within infected and non-infected population. Weight found to be significant i.e. p-0.005 among group 1 and group 2 . It shows that mean weight of infected group is less then non-infected group. BMI found to be non significant among infected and noninfected group. Vitamin D found to be significant i.e. pless then 0.02 among group 1 and group 2 .

Figure1.1Comparison of mean values in two groups on the basis of weight

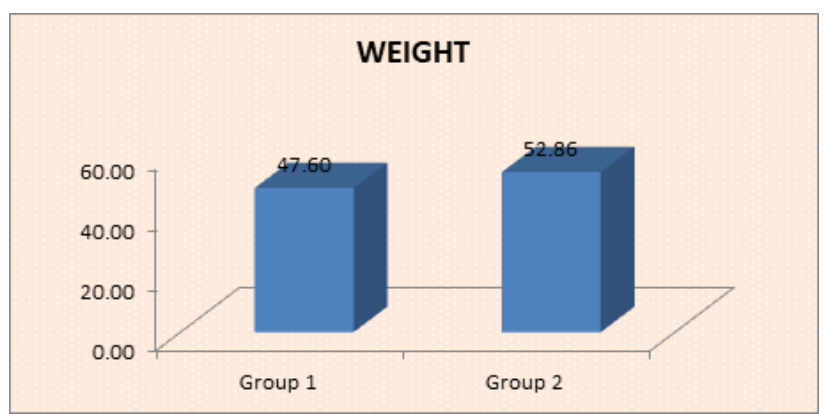

Figure1.2 Comparison of mean values in two groups on the basis of BMI

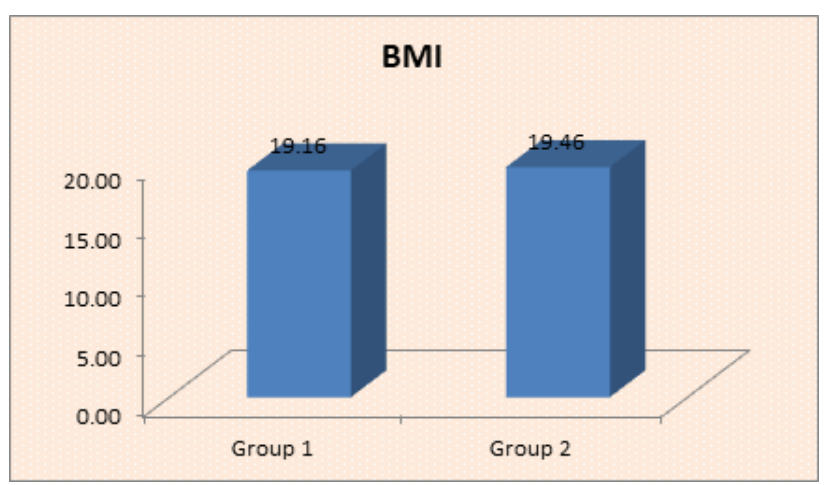

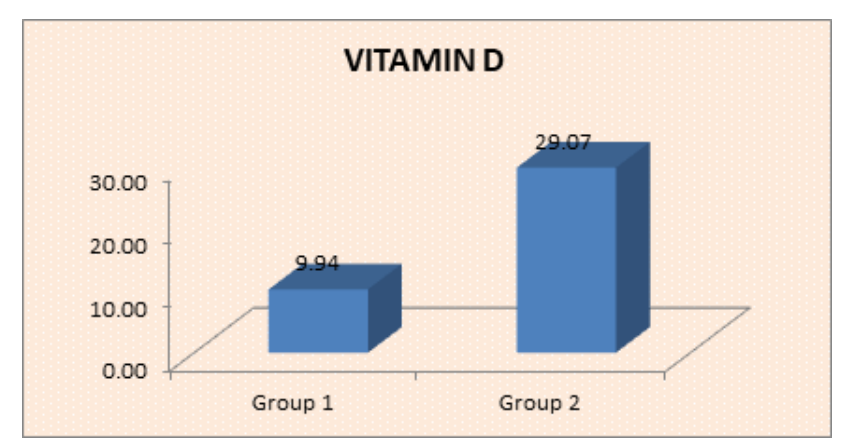

Table 1.2 Correlation between the variables

\begin{tabular}{|l|l|l|l|l|}
\hline & & $\begin{array}{l}\text { VITAMIN } \\
\mathrm{D}\end{array}$ & BMI & WEIGHT \\
\hline $\begin{array}{l}\text { VITAMIN } \\
\mathrm{D}\end{array}$ & $\begin{array}{l}\mathrm{P} \\
\text { value }\end{array}$ & - & 0.313 & $<0.001$ \\
\hline BMI & $\begin{array}{l}\mathrm{P} \\
\text { value }\end{array}$ & 0.313 & - & $<0.001$ \\
\hline WEIGHT & $\begin{array}{l}\mathrm{P} \\
\text { value }\end{array}$ & $<0.001$ & $<0.001$ & - \\
\hline
\end{tabular}

The above table1.2 shows that Vitamin $\mathrm{D}$ was significantly correlated with weight ( $p$ value $<0.001)$ also non significant with Body Mass Index ( $\mathrm{p}$ value- 0.313). Weight was positively and significantly correlated with BMI (p<value 0.001).

\section{DISCUSSIONS \& RESULTS}

The association between $\mathrm{Tb}$ and deficiency of fatsoluble vitamin $D$ is significant because $p$ value is $<0.001$. For $\mathrm{Tb}$ vitamin $\mathrm{D}$ is a predisposing factor rather than a concern. Reduced plasma concentration of calciferol has been found in TB subjects as compared to

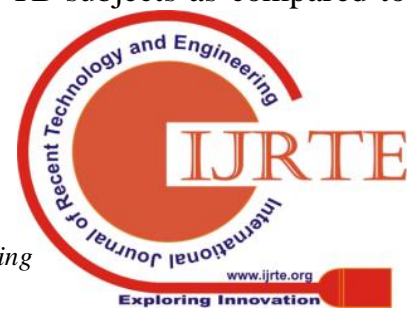


non-infected subjects. According to the results obtained after analysis it was showed that calciferol levels were below the normal range in both the cases but tuberculosis infected subjects had extremely lesser amount vitamin D levels.

Vitamin D is positively as well as significantly related with weight and non-significant with the BMI. There is a remarkable decrease in levels of vitamin D with increase in BMI. Individuals having high BMI usually have high levels of adipose tissue, that act as a loch for vitamin D (lipid soluble), and vitamin D liberation from the adipose tissue is very low. Therefore, exceeding desirable amount of body fat caused increased sequestration and low accessibility of vitamin D.

The mean weight of an infected group is less then the non-infected group i.e. 47.60 and 52.86 respectively. Treatment failure results in weight loss and moderate and severe malnutrition is a risk factor linked with early mortality during $\mathrm{Tb}$ treatment in low-income groups.

Lowe BMI is significantly associated with $\mathrm{Tb}$ infection and large amount of adipose tissue negatively impacts the host defence and immune system Low BMI alters the immune system ad increase the susceptibility to $\mathrm{Tb}$ infection. The prevalence of $\mathrm{Tb}$ infection is higher in underweight patients than obese people.

There is a positive link of vitamin D deficiency as well as $\mathrm{Tb}$ because $\mathrm{p}$ value $<0.001$. Reduced calciferol levels were resulted in patients with $\mathrm{Tb}$ compared with noninfected subjects. Vitamin D established to be lesser in both infected and non-infected group but more little in infected group when compared with healthy group.

Vitamin D is significantly related with weight and non significant with the BMI. There is a remarkable decline in vitamin D levels with increase in BMI. People with higher BMI usually have higher adipose tissue level, which behave as storage for lipid soluble vitamin D, and release of vitamin $\mathrm{D}$ from the fat tissue is extremely low. Therefore, large amount of body fat results in the elevated segregation and shortage of calciferol.

In the present study, general population itself was highly deficient in vitamin D. Hence; it's difficult to delineate a link between TB and vitamin D. In future, a multicentre study with relatively greater sample size needs to be carried out to elicit a link within TB as well as calciferol levels.

\section{CONCLUSION}

The study concluded that level of vitamin D is linked with growth of tuberculosis bacteria in human body. Treatment of vitamin D deficiency can help faster recovery of patient if the other medication of $\mathrm{Tb}$ is administered by patient time to time also the higher value of BMI which in turn increase the fat tissue in the body can alter the recovery process in a negative side because of some chemical properties of vitamin and fat tissue, Therefore, It has also been concluded from the that weight management can also trigger the process of recovery in $\mathrm{Tb}$ patient.

\section{REFRENCES}

1. Holick M.F. High prevalence of vitamin D inadequacy and implications for health. Mayo Clin Proc. 2006;81(3):353373 .

2. Wilkinson R.J., Llewelyn M., Toossi Z., Patel P., Pasvol G., Lalvani A. Influence of vitamin D deficiency and vitamin D receptor polymorphisms on tuberculosis among Gujarati Asians in west London: a case-control study. Lancet. 2000;355(9204):618-621.[

3. Lemire J.M. Immunomodulatory role of 1,25dihydroxyvitamin D3. J Cell Biochem. 1992;49(1):26-31.

4. Reichel H., Koeffler H.P., Tobler A., Norman A.W. 1 alpha, 25-Dihydroxyvitamin D3 inhibits gamma-interferon synthesis by normal human peripheral blood lymphocytes. ProcNatlAcadSci U S A. 1987;84(10):33853389

5. Rachez C., Freedman L.P. Mechanisms of gene regulation by vitamin $\mathrm{D}(3)$ receptor: a network of coactivator interactions. Gene. 2000;246(1-2):9-21.

6. Bhalla A.K., Amento E.P., Clemens T.L., Holick M.F., Krane S.M. Specific high-affinity receptors for 1,25dihydroxyvitamin D3 in human peripheral blood mononuclear cells: presence in monocytes and induction in $\mathrm{T}$ lymphocytes following activation. J ClinEndocrinolMetab. 1983;57(6):1308-1310

7. Stumpf W.E., Sar M., Reid F.A., Tanaka Y., DeLuca H.F. Target cells for 1,25-dihydroxyvitamin D3 in intestinal tract, stomach, kidney, skin, pituitary, and parathyroid. Science. 1979;206(4423):1188-1190

8. Yim S., Dhawan P., Ragunath C., Christakos S., Diamond G. Induction of cathelicidin in normal and $\mathrm{CF}$ bronchial epithelial cells by 1,25-dihydroxyvitamin $\mathrm{D}(3) \mathrm{J}$ Cyst Fibros. 2007;6(6):403-410. ]

9. Hansdottir S., Monick M.M., Hinde S.L., Lovan N., Look D.C., Hunninghake G.W. Respiratory epithelial cells convert inactive vitamin $\mathrm{D}$ to its active form: potential effects on host defense. J Immunol. 2008;181(10):7090 7099.

10. Liu P.T., Stenger S., Li H., Wenzel L., Tan B.H., Krutzik S.R. Toll-like receptor triggering of a vitamin D-mediated human response. Science. 2006;311(5768):1770-1773.

11. Liu P.T., Schenk M., Walker V.P., Dempsey P.W., Kanchanapoomi M., Wheelwright M. Convergence of IL1beta and VDR activation pathways in human TLR2/1induced antimicrobial responses. PLoS One. 2009;4(6) e5810.

12. Martineau A.R., Wilkinson K.A., Newton S.M., Floto R.A., Norman A.W., Skolimowska K. IFN-gamma- and TNF-independent vitamin D-inducible human suppression of mycobacteria: the role of cathelicidin LL-37. J Immunol. 2007;178(11):7190-7198.

13. Wang T.T., Nestel F.P., Bourdeau V., Nagai Y., Wang Q., Liao J. Cutting edge: 1,25-dihydroxyvitamin D3 is a direct inducer of antimicrobial peptide gene expression. J Immunol. 2004;173(5):2909-2912.

14. Coussens A., Timms P.M., Boucher B.J., Venton T.R., Ashcroft A.T., Skolimowska K.H. 1alpha,25dihydroxyvitamin D3 inhibits matrix metalloproteinases induced by Mycobacterium tuberculosis infection. Immunology. 2009;127(4):539-548.

15. Reinehr T, de SG, Alexy U, Kersting M, Andler W. Vitamin D status and parathyroid hormone in obese children before and after weight loss. Eur $J$ Endocrinol. 2007;157:225-232. doi: 10.1530/EJE-07-0188 
16. Barrera D, Avila E, Hernandez G, Halhali A, Biruete B, Larrea F, et al. Estradiol and progesterone synthesis in human placenta is stimulated by calcitriolJ Steroid BiochemMol Biol.J Steroid BiochemMol Biol. 2007;103(3-5):529-532.

17. Gallagher D, Heymsfield SB, Heo M, Jebb SA, Murgatroyd PR, Sakamoto Y. Healthy percentage body fat ranges: an approach for developing guidelines based on body mass index. Am J ClinNutr. 2000;72(3):694-701.

18. Wortsman J, Matsuoka LY, Chen TC, Lu Z, Holick MF. Decreased bioavailability of vitamin D in obesity. Am J ClinNutr. 2000;72(3):690-693.

19. Rosenstreich SJ, Rich C, Volwiler W. Deposition in and release of vitamin D3 from body fat: evidence for a storage site in the rat. J Clin Invest. 1971;50:679-687. doi: $10.1172 / \mathrm{JCI} 106538$.

20. Bolland MJ, Grey AB, Ames RW, Horne AM, Mason BH, Wattie DJ, et al. Age-, gender-, and weightrelated effects on levels of 25-hydroxyvitamin D are not mediated by vitamin D-binding protein. ClinEndocrinol (Oxf) 2007;67(2):259-264. doi: 10.1111/j.13652265.2007.02873.x . 